\title{
EFFECT OF AXIAL FORCE AND FIBRE TYPE ON THE SHEAR BEHAVIOR OF HIGH STRENGTH FIBER REINFORCED CONCRETE BEAMS
}

\author{
I G Shaaban \\ Zagazig University \\ Egypt
}

\begin{abstract}
This study is part of a larger research work aimed to study the effects of fiber content, fiber type (corrugated shape and hooked-end), amount of web reinforcement and axial compression stress, on the shear behavior of high strength fiber reinforced concrete (HSFRC) beams. To the author's knowledge, the effect of applying axial compression forces, to the HSFRC beams, has not yet been studied. Nineteen simply supported HSFRC beams were subjected to axial compression forces and tested under two-point vertical loading for three values of shear span to depth ratio. It was found that the shear strength of beams subjected to axial compression stress level equals 0.1 , is higher than that in the literature for beams tested without applying axial stress by a range of $22 \%-98 \%$. Increasing the axial compression stress level to 0.2 led to an increase in the first crack load, ultimate load by $24 \%$ and $10 \%$, a reduction in the deflection by $(19-30 \%)$, compared with those subjected to axial compression stress level equals 0.1. In addition, a combination of web reinforcement and fibers resulted in a significant increase in the cracking and ultimate loads by 123 and $59 \%$, respectively, over those of the reference beam. A new formula is proposed for predicting the experimental shear strength of HSFRC beams subjected to axial compression forces. The results obtained by the proposed formula are in better agreement with the test results when compared with the predictions based on the empirical equations proposed by other investigators.
\end{abstract}

Keywords: Steel fibers, High strength concrete beams, Hooked-end fibers, Corrugated fibers, Shear, Prediction, Empirical equations.

I G Shaaban is an associate professor for the analysis and design of RC structures in the Civil Engineering Department at Zagazig University (Banha Branch), Cairo, Egypt. He obtained his MSc from Ain Shams University, Cairo, Egypt, in 1988 and his PhD from the University of Dundee, Scotland, UK, in 1993. His research interests include the structural behavior of RC, FRC and high strength concrete structures (HSC), analysis and prediction of such structures, repair and strengthening of RC structures, concrete durability and its relation to the design of reinforced concrete structures. 


\section{INTRODUCTION}

High Strength Concrete (HSC) is considered to be a relatively brittle material because the post-peak portion of its stress-strain diagram descends deeply as compressive strength increases [1 and 2]. When added to concrete mixes, steel fibers distribute randomly through the mix at much closer spacings than conventional reinforcing steel and act to arrest cracking by decreasing the stress intensity factor at the tip of inherent internal cracks [3]. This leads to increasing the shear-friction strength of concrete and also improves the ultimate tensile strength and ductility because a lot of energy is absorbed in debonding and pulling out of fibers from the concrete before complete separation and failure of concrete occurs [3]. Swamy and Bahia [4] showed that fibers act as effective shear reinforcement, much like the legs of regularly spaced stirrups, and are more effective in arresting crack propagation and maintaining the integrity of the surrounding concrete. Ashour et al. [2] and Craig [5] showed that it is possible to replace stirrups partially or completely with fibers in beams of HSC under transverse loading to resist shear. The ACI Committee 544 [6] defined the FRC as a concrete with increased strain capacity, impact resistance, energy absorption, and tensile strength. It has been clearly shown that for beams reinforced with a fixed amount of minimum shear reinforcement, irrespective of the concrete strength, the reserve shear strength diminishes as the concrete strength gets higher [ 7 and 8$]$. Therefore, the minimum shear reinforcement for HSC either in the form of stirrups, fibers or both needs more investigation.

Despite that the behaviour of reinforced concrete $(\mathrm{RC})$ beams in flexure and shear was examined in the literature using an independent test specimen without restraints, $\mathrm{RC}$ beams in real concrete structures are members of a frame structure and they behave differently from such idealized members because of the axial restraint imposed by adjacent members [9]. Based on experiments and analyses, researchers [10] have concluded that reinforced concrete member's characteristics, such as capacity and failure pattern in compression, are significantly different under restraint conditions. From a study performed by Yang et al. [9] it was shown that the flexural and shear behavior characteristics and the failure pattern of RC flexural members is governed by the intensity of axial restraints. Abdoun [11] studied the effect of axial compression forces on the behavior of HSC beams with web reinforcement. To date, an organized and comprehensive evaluation considering the effect of applying axial compression forces to the fiber reinforced HSC beams without web reinforcement, has not been attempted.

The aim of this research is to study the effect of varying the fiber type, fiber content and the axial compression forces on the shear behavior of HSFRC beams. All studied beams were subjected to axial compression forces and then tested by two-point transverse loading. The resulting first-crack loads and ultimate shear loads were compared with those of a plain concrete reference beam to assess the contribution of the fibers. A proposed formula was developed for prediction of shear strength of studied beams to a high degree of accuracy.

\section{EXPERIMENTAL PROGRAMME}

\section{Preparation of Beam Specimens and Testing}

Mix proportions for HSC used in this study are shown in Table 1. Steel fibers of varying amounts and types (see Table 2) were added during mixing of the concrete. Two types of fibers were used, namely, hooked-end and corrugated steel fibers of yield strength of 400 $\mathrm{MPa}$. The aspect ratio of the two types of fibers was constant $\left(\ell / \mathrm{d}_{\mathrm{f}}=50 \mathrm{~mm} / 1 \mathrm{~mm}=50\right)$. Dimensions and details of specimens used in this research are shown in Table 2 and Figure 1. 
It should be noted that all beams were over-reinforced in flexure to ensure shear failure. The tested beam specimens were subjected to axial compression force prior to testing by twopoint transverse loading (shear span-to depth ratio, a / d $=2,3$ and 4). All beams were statically tested to failure in a single load cycle. A Linear Variable Differential Transducer (LVDT) was used to measure deflection, strains at bottom bars and stirrups from the electrical strain gauges through a computer-controlled data acquisition system.

Table 1 Mix Constituent Proportions for the Studied Beams

\begin{tabular}{ccccccc}
\hline \multirow{2}{*}{$\begin{array}{c}\text { CHARACTERISTIC } \\
\text { STRENGTH }\end{array}$} & Cement & Sand & $\begin{array}{c}\text { Crushed } \\
\text { Basalt }\end{array}$ & $\begin{array}{c}\text { Silica } \\
\text { Fume }\end{array}$ & Water & $\begin{array}{c}\text { Superplasticizer } \\
\text { Liter/ } \mathrm{m}^{3}\end{array}$ \\
\hline $80 \mathrm{MPa}$ & 550 & 600 & 1250 & 55 & 150 & 23 \\
\hline
\end{tabular}
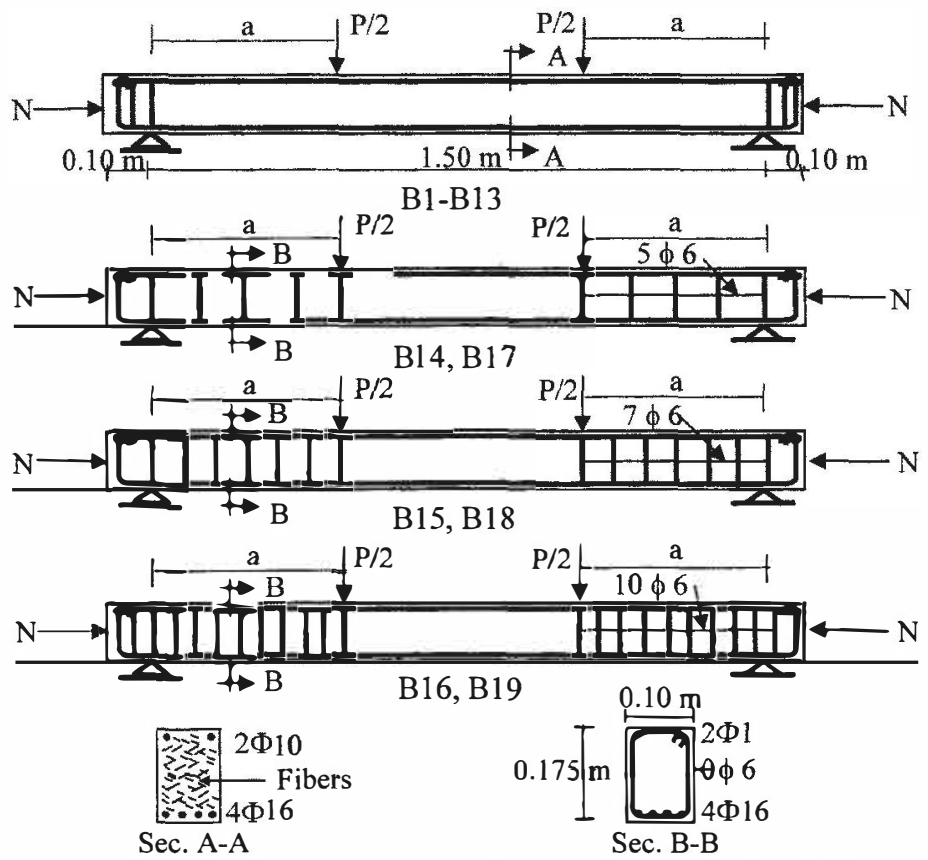

$\mathrm{a}=0.45 \mathrm{~m}$ for all beams except for $\mathrm{B} 7, \mathrm{a}=0.30 \mathrm{~m}$ and $\mathrm{B} 8, \mathrm{a}=0.60 \mathrm{~m}$

All beams contain steel fibers except B13-B16

$\mathrm{N}=0.2 \mathrm{f}_{\mathrm{cu}} \times \mathrm{Ac}$ for Beams B4-B6, B11 and B12.

$\mathrm{N}=0.1 \mathrm{f}_{\mathrm{cu}} \times \mathrm{Ac}$ for all other beams.

Figure 1 Dimensions, reinforcement details and loading of the studied beams 
Table 2 Experimental Programme for Studied Specimens

\begin{tabular}{|c|c|c|c|c|c|c|}
\hline $\begin{array}{c}\text { BEAM } \\
\text { SPECIMEN } \\
\text { NUMBER }\end{array}$ & $\begin{array}{c}\mathrm{f}_{\mathrm{cu}}, \\
\mathrm{MPa}\end{array}$ & $\begin{array}{c}\text { AXIAL } \\
\text { COMPRESSION } \\
\text { STRESS } \\
\left(\mathrm{N} / \mathrm{f}_{\mathrm{cu}} \mathrm{A}_{\mathrm{c}}\right)\end{array}$ & $\begin{array}{l}\text { TYPE OF } \\
\text { STEEL } \\
\text { FIBERS }\end{array}$ & $\begin{array}{c}\text { VOLUME } \\
\text { CONTENT } \\
\text { OF } \\
\text { FIBERS, } \\
v_{f}, \%\end{array}$ & $\begin{array}{c}\text { SHEAR } \\
\text { SPAN/ } \\
\text { DEPTH } \\
\text { RATIO } \\
\text { a/d }\end{array}$ & $\begin{array}{c}\text { WEB } \\
\text { REINFORCEMENT } \\
\text { RATIO, } \mu_{\mathrm{v}} \%\end{array}$ \\
\hline $\mathrm{Bl}$ & 90 & 0.1 & Hooked-end & 0.5 & 3 & - \\
\hline B2 & 91 & 0.1 & Hooked-end & 1.0 & 3 & - \\
\hline B3 & 90 & 0.1 & Hooked-end & 1.5 & 3 & - \\
\hline B4 & 84 & 0.2 & Hooked-end & 0.5 & 3 & - \\
\hline B5 & 77 & 0.2 & Hooked-end & 1.0 & 3 & - \\
\hline B6 & 76 & 0.2 & Hooked-end & 1.5 & 3 & - \\
\hline B7 & 84 & 0.1 & Hooked-end & 1.0 & 2 & - \\
\hline B8 & 79 & 0.1 & Hooked-end & 1.0 & 4 & - \\
\hline B9 & 85 & 0.1 & Corrugated & 0.5 & 3 & - \\
\hline B10 & 86 & 0.1 & Corrugated & 1.0 & 3 & - \\
\hline B11 & 79 & 0.2 & Corrugated & 0.5 & 3 & - \\
\hline B12 & 80 & 0.2 & Corrugated & 1.0 & 3 & - \\
\hline B13 & 78 & 0.1 & - & - & 3 & - \\
\hline B14 & 78 & 0.1 & - & - & 3 & 0.50 \\
\hline B15 & 79 & 0.1 & - & - & 3 & 0.75 \\
\hline B16 & 78 & 0.1 & - & - & 3 & 1.12 \\
\hline B17 & 84 & 0.1 & Hooked-end & 0.5 & 3 & 0.50 \\
\hline B18 & 80 & 0.1 & Hooked-end & 0.5 & 3 & 0.75 \\
\hline B19 & 82 & 0.1 & Hooked-end & 0.5 & 3 & 1.12 \\
\hline
\end{tabular}

\section{EXPERIMENTAL RESULTS AND DISCUSSION}

\section{General Behavior, Crack Pattern and Failure Mode}

Figure 2 shows the crack pattern and failure mode for all the tested beams. The first crack load, ultimate load capacity and modes of failure for the tested beams are listed in Table 3. Generally, the first crack for all beams occurred in the shear region perpendicular to the direction of the maximum principal stress induced by pure shear. 
Despite that the type and amount of steel fibers did not change the mode of failure, they transformed the failure mode into a more ductile one, or in other words, they raised the value of the first crack and ultimate loads as shown in Table 3.

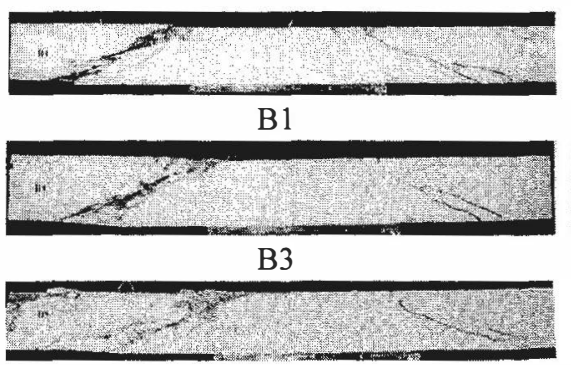

B5

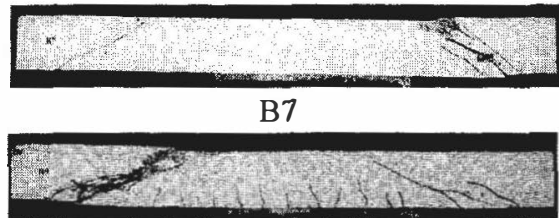

B9

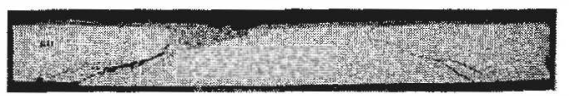

B 11

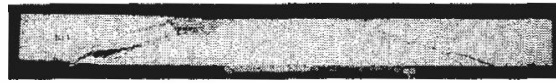

B13

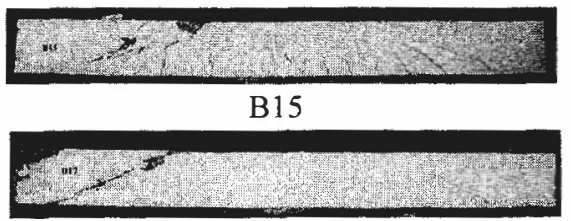

$\mathrm{B} 17$

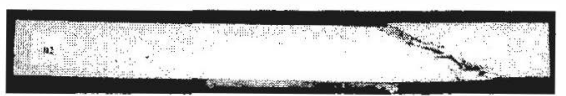

B2

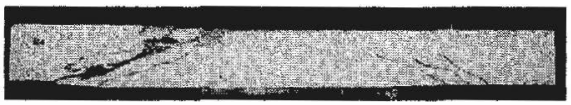

B4

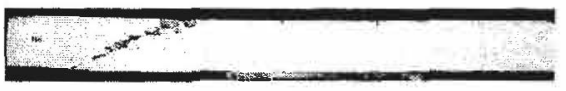

B6

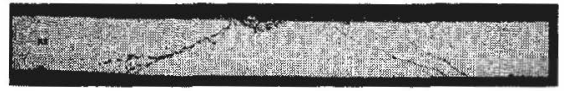

B8

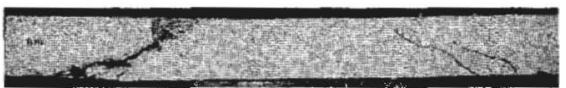

B10

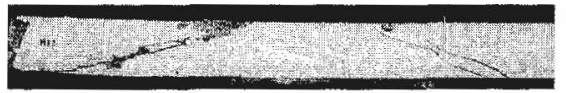

$\mathrm{B} 12$

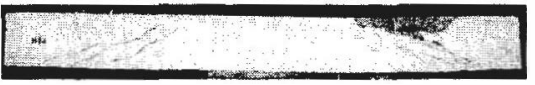

B14

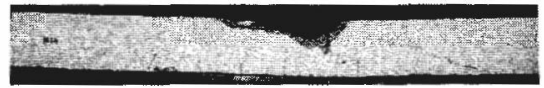

B16

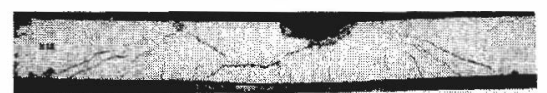

$\mathrm{B} 18$

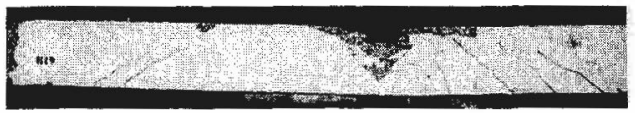

B 19

Figure 2 Crack pattern and failure mode for studied beam specimens.

For example, adding $0.5 \%$ fibers by volume resulted in increasing the cracking load and ultimate load for B1 by 14 and $17 \%$, over those of the reference beam, B13. Increasing the fiber volume to $1.5 \%$ led to a further increase to cracking and ultimate loads for B3 by 41 and $48 \%$, compared to those of the reference beam, B 13 . It was also observed that beams without web reinforcement had only a single diagonal crack on one end of the beam extending 
throughout the shear span (Beams B1-B13). In addition, Table 3 shows that the hooked-end fibers are slightly better than corrugated steel fibers in terms of raising the first crack load, increasing the capacity and ductility of studied beams. For example, Beams B1 and B2 (contains hooked-end fibers and subjected to axial compression stress level equals 0.1 ) had a first crack load, failure load and, in turn, ductility higher than those of Beams B9 and B10 (contains corrugated steel fibers), but the failure mode did not change. Balaguru and Shah [12] reported the superior properties of hooked-end fibers over the other steel fibers.

Table 3 Cracking, Maximum Shear Load, and Failure Mode of the Test Beams

\begin{tabular}{|c|c|c|c|c|c|c|c|c|}
\hline BEAM & $\begin{array}{c}\mathrm{f}_{\mathrm{cu}} \\
\mathrm{MPa}\end{array}$ & $\mathrm{a} / \mathrm{d}$ & $\begin{array}{c}\text { FIBER } \\
\text { TYPE \& } \\
\text { CONTENT, } \\
\mathbf{v}_{\mathbf{f}}, \%\end{array}$ & ACS & $\mu_{\mathrm{v}}, \%$ & $\begin{array}{l}\mathrm{P}_{\mathrm{cr}} \\
\mathrm{kN}\end{array}$ & $\begin{array}{l}\mathrm{P}_{\mathrm{u}} \\
\mathrm{kN}\end{array}$ & FAILURE MODE \\
\hline B1 & 90 & 3 & HE, 0.5 & 0.1 & - & 121 & 186 & Shear \\
\hline B2 & 91 & 3 & HE, 1.0 & 0.1 & - & 132 & 200 & Shear \\
\hline B3 & 90 & 3 & HE, 1.5 & 0.1 & - & 149 & 236 & Shear \\
\hline B4 & 84 & 3 & HE, 0.5 & 0.2 & - & 150 & 205 & Shear \\
\hline B5 & 77 & 3 & HE, 1.0 & 0.2 & -. & 155 & 212 & Shear \\
\hline B6 & 76 & 3 & HE, 1.5 & 0.2 & -- & 166 & 244 & Shear \\
\hline B7 & 84 & 2 & HE, 1.0 & 0.1 & -- & 180 & 288 & Shear \\
\hline B8 & 79 & 4 & HE, 1.0 & 0.1 & -- & 93 & 152 & Shear \\
\hline B9 & 85 & 3 & $\mathrm{CR}, 0.5$ & 0.1 & -- & 117 & 185 & Shear \\
\hline $\mathrm{B} 10$ & 86 & 3 & $\mathrm{CR}, 1.0$ & 0.1 & - & 130 & 194 & Shear \\
\hline B11 & 79 & 3 & $\mathrm{CR}, 0.5$ & 0.2 & -- & 132 & 197 & Shear-Compression \\
\hline B12 & 80 & 3 & $\mathrm{CR}, 1.0$ & 0.2 & -- & 157 & 201 & Shear-Compression \\
\hline $\mathrm{B} 13$ & 78 & 3 & -- & 0.1 & - & 106 & 159 & Shear \\
\hline B14* & 78 & 3 & -- & 0.1 & 0.5 & 160 & 199 & Shear-Compression \\
\hline $\mathrm{B} 15^{*}$ & 79 & 3 & - & 0.1 & 0.75 & 174 & 234 & Shear \\
\hline B16* & 78 & 3 & -- & 0.1 & 1.12 & 210 & 236 & Compression \\
\hline $\mathrm{B} 17^{*}$ & 84 & 3 & HE, 0.5 & 0.1 & 0.5 & 192 & 215 & Shear \\
\hline B18* & 80 & 3 & HE, 0.5 & 0.1 & 0.75 & 227 & 249 & Compression \\
\hline B19* & 82 & 3 & HE, 0.5 & 0.1 & 1.12 & 236 & 253 & Compression \\
\hline
\end{tabular}

$\overline{\mathrm{ACS}}=$ axial compression stress, $\mathrm{P}_{\mathrm{u}}=$ ultimate load, $\mathrm{P}_{\mathrm{cr}}=$ cracking load, $\mathrm{HE}=$ hooked-end fibers, $\mathrm{CR}=$ corrugated steel fibers.

* Beams with web reinforcement "stirrups"

It was observed that the number of inclined cracks increased with the presence of web reinforcement, indicating an enhanced redistribution of internal forces (Beams B14-B19). The combination of fibers and web reinforcement (B17-B19) resulted in a significant increase in the cracking loads $(81-123 \%)$ and ultimate loads $(35-59 \%)$ over those of the reference 
specimen B13. This is in agreement with the findings of Johnson and Ramirez [7]. For Beams B14, the mode of failure was shear-compression, but adding steel fibers in B17 resulted in raising the first crack load and ultimate load by 20 and $8 \%$, respectively. Increasing the amount of transverse reinforcement in B15 resulted in propagation of flexural cracks in the beam but the mode of failure was shear.

Adding fibers to the mix, B18 led to improving the shear behavior and changing of failure mode and the beam failed in flexure with crushing of concrete and yielding of compression steel in top of the beam. Further increase to the web reinforcement, B16, led to decreasing the cracks spacing, increasing the number of cracks and changing the failure mode to compression failure, since the tension zone was over reinforced.

In addition, increasing the applied axial compression stress from 0.1 to 0.2 led to increasing the first crack load and ultimate load. For example, increasing the applied axial compression stress from 0.1 for $\mathrm{B} 1, \mathrm{~B} 2$ and $\mathrm{B} 3$ to 0.2 for $\mathrm{B} 4, \mathrm{~B} 5$ and $\mathrm{B} 6$ led to increasing the cracking loads by 24,17 and $11 \%$ and ultimate loads by 10,6 and $3 \%$, for these beams, respectively. It is interesting to notice that the effect of increase in axial compression stress becomes less significant with the increase of percentage volume of fibers from $0.5 \%$ to $1.5 \%$.

\section{PREDICTION OF SHEAR STRENGTH}

\section{Proposed Equation for Predicting Shear Strength Results}

Based on the author's experimental results, the equation developed by Oh et al. [13] for normal strength FRC was modified to predict the experimental results in this investigation. In the formulation of the equilibrium requirements for a loaded FRC beam, the external and internal actions shown in the free body diagram of a part of the shear span of a simply supported FRC beam (Figure 3) is identified and the shear force, $V_{u}$ can be written in its general form as

$$
\mathrm{V}_{\mathrm{u}}=\mathrm{V}_{\mathrm{c}}+\mathrm{V}_{\mathrm{ay}}+\mathrm{V}_{\mathrm{d}}+\mathrm{V}_{\mathrm{fy}}
$$

Where $V_{c}$ is the shear force across the compression zone resisted by concrete, $V_{a y}$ is the aggregate interlocking force (vertical component), $V_{d}$ is the dowel action force, and $V_{f y}$ is the vertical component of the fiber pullout force along the inclined crack, $V_{f y}=F_{1}(h-c) / d$.

The contribution of the aggregate interlocking was ignored in this study since it has been reported in the literature [14] that the crack plane in HSC is relatively smooth and passes through the aggregate instead of going around it, as in normal-strength concrete. Such a phenomenon results in a reduced contribution of aggregate interlocking in a diagonally cracked HSC concrete beam [14]. Thus the equation of shear strength was written as;

$$
\begin{aligned}
& V_{u}=\left(10 \rho f_{c}^{\prime} d / a_{s}\right)^{1 / 3} b d+A_{v} f_{y} d / s+F_{1}(h-c) / d \quad \text { for } a_{s} / d \geq 2.5 \\
& V_{u}=\left(160 \rho f_{c}^{\prime}\right)^{1 / 3}\left(d / a_{s}\right)^{4 / 3} b d+A_{v} f_{y} d / s+F_{1}(h-c) / d \quad \text { for } a_{s} / d<2.5
\end{aligned}
$$

where

$\mathrm{a}_{\mathrm{s}}$ is the shear span, $\mathrm{mm}$

$\mathrm{b}$ is the breadth of beam section, $\mathrm{mm}$

$\mathrm{A}_{\mathrm{v}}$ is the area of stirrups, $\mathrm{mm}^{2}$

$\mathrm{s}$ is the spacing of the stirrups, $\mathrm{mm}$

$\mathrm{f}_{\mathrm{y}}$ is the yield strength of the stirrups, $\mathrm{MPa}$

$F_{1}$ is the ultimate force sustained by the steel fibers per unit area of crack at failure.

$\mathrm{h}$ is the total height of the beam, $\mathrm{mm}$

$\mathrm{c}$ is the neutral axis depth, $\mathrm{mm}$ 


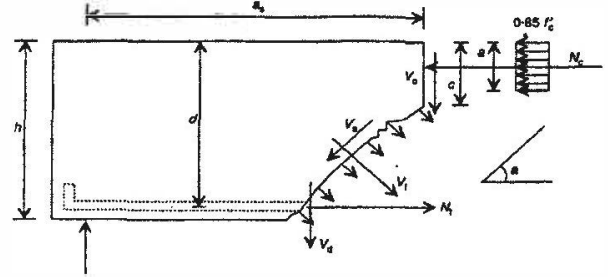

(a) Free body diagram of part of the shearspan of a simply supported FRC beam [13].

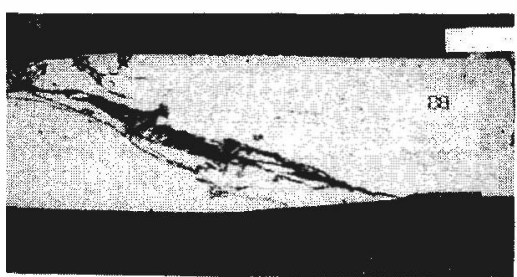

(b) A photo showing the fibers at the surface of the diagonal crack of one of the tested beams in this investigation.

Figure 3 Contribution of concrete, fibers and stirrups in shear strength.

Four major modifications were made to Equation (1) in order to be applicable for HSFRC beams subjected to axial compression forces. Firstly, the contribution of steel fibers was modified to be as suggested by Narayanan and Darwish [15]. Secondly, the effect of axial compression forces, stated in the codes [16 and 17], was included in the proposed equation. Thirdly, after carrying out a regression analysis for the beams tested in this study, the multipliers 10 and 160 were changed to be 23 and 660 in order to reflect the behavior of HSC. Finally, the contribution of the web reinforcement "stirrups", $V_{\text {us, }}$ was multiplied by a reduction factor, 0.9, since the steel fibers share the stirrups in resisting shear strength. Therefore the proposed equation becomes:

$$
\begin{aligned}
& \text { for } \mathrm{a}_{\mathrm{s}} / \mathrm{d} \geq 2.5 \\
& V_{u}=\left[\left(23 \rho f_{c}{ }^{\prime} d / a_{s}\right)^{1 / 3} b d+0.9 A_{v} f_{y} d / s+0.41 \tau F\right]\left(1+0.07 N / A_{c}\right) \\
& \text { and for } \mathrm{a}_{\mathrm{s}} / \mathrm{d}<2.5 \\
& V_{u}=\left[\left(660 \rho f_{c}{ }^{\prime}\right)^{1 / 3}\left(d / a_{s}\right)^{4 / 3} b d+0.9 A_{v} f_{y} d / s+0.41 \tau F\right]\left(1+0.07 N / A_{c}\right)
\end{aligned}
$$

where $\mathrm{N}=$ axial compression force applied to the beam

$A_{c}=b d$ (cross sectional area of beam section)

Table 4 shows a comparison between the modified equations in the literature, which were originally proposed by Ashour et al. [2], Farahat [18], and Narayanan and Darwish [15], and the proposed equation in predicting the experimental results in this investigation. The equations in the literature were modified by multiplying their results by the factor $(1+0.07 \mathrm{~N}$ $\left(\mathrm{A}_{\mathrm{c}}\right.$ ) in order to include the effect of axial compression forces. This factor was included in the ACI Building Code equation [16] and the ECCS Code equation [17]. It can be seen from Table 4 that the equations developed by Ashour et al. [2], Farahat [18] and Narayanan and Darwish [15] improved greatly after including the effect of axial compression forces. The ratio of the experimental to the predicted shear strength by the modified equation developed earlier by Farahat [18] has a mean of 1.04 and a standard deviation of 0.14 , while that of the Narayanan and Darwish equation [15] has a mean of 1.1 with a standard deviation of 0.12 and Ashour et al. equation [2] predicted the results with a mean ratio of 1.18 and a standard deviation of 0.15 . The proposed equation predicted the results very accurately with a mean of the experimental to the predicted results equals 1.0 and the standard deviation was 0.08 only. In order to assess the effect of axial compression forces applied to the studied beams, a comparison was made in Table 4 between the shear strength results in the current investigation and those tested by Farahat [18] and not subjected to axial compression forces. 
It can be seen that shear strength results for beams subjected to axial compression forces are higher than those tested without applying axial forces by a range of $22-98 \%$.

Table 4 Comparison between the proposed equation and equations in literature, modified to count for axial loading, in Predicting Shear Strength

\begin{tabular}{|c|c|c|c|c|c|c|c|}
\hline \multirow[b]{2}{*}{ BEAM } & \multirow[b]{2}{*}{$\begin{array}{l}\text { LEVEL OF } \\
\text { AXIAL } \\
\text { COMP. } \\
\text { STRESS }\end{array}$} & \multirow[b]{2}{*}{$\begin{array}{l}\text { fcu, } \\
\mathrm{MPa}\end{array}$} & \multirow[b]{2}{*}{$\begin{array}{c}\text { OBSERVED } \\
\text { SHEAR } \\
\text { STRENGTH, } v_{w o}, \\
\mathrm{Mpa}\end{array}$} & \multicolumn{4}{|c|}{ EXPERIMENTAL / PREDICTED SHEAR STRENGTH, $v_{u} / v_{p}$} \\
\hline & & & & $\begin{array}{c}\text { NARAYANAN } \\
\text { AND DARWISH } \\
{[15]}\end{array}$ & $\begin{array}{l}\text { ASHOUR et } \\
\text { al. [2] }\end{array}$ & $\begin{array}{c}\text { FARAHAT } \\
\text { [18] }\end{array}$ & $\begin{array}{l}\text { PROPOSE } \\
\text { D Eq. (2) }\end{array}$ \\
\hline B1 & 0.1 & 90 & $6.2(3.33)$ & 1.21 & 1.29 & 1.15 & 1.05 \\
\hline B2 & 0.1 & 91 & $6.7(4.13)$ & 1.15 & 1.15 & 1.04 & 1.01 \\
\hline B3 & 0.1 & 90 & 7.9 & 1.22 & 1.18 & 1.07 & 1.09 \\
\hline B4 & 0.2 & 84 & 6.8 & 1.02 & 1.1 & 0.98 & 0.90 \\
\hline B5 & 0.2 & 77 & 7.1 & 0.99 & 1.01 & 0.92 & 0.89 \\
\hline B6 & 0.2 & 76 & 8.1 & 1.02 & 1.0 & 0.92 & 0.93 \\
\hline B7 & 0.1 & 84 & $9.6(7.85)$ & 1.23 & 1.17 & 0.75 & 1.01 \\
\hline B8 & 0.1 & 79 & $5.1(3.77)$ & 1.0 & 1.28 & 0.98 & 0.91 \\
\hline B9 & 0.1 & 85 & 6.2 & 1.27 & 1.42 & 1.26 & 1.14 \\
\hline B10 & 0.1 & 86 & 6.5 & 1.17 & 1.27 & 1.14 & 1.08 \\
\hline B11 & 0.2 & 79 & 6.6 & 1.04 & 1.17 & 1.03 & 0.93 \\
\hline B12 & 0.2 & 80 & 6.7 & 0.94 & 1.02 & 0.91 & 0.86 \\
\hline $\mathrm{B} 13$ & 0.1 & 78 & $5.3(2.67)$ & 1.36 & 1.56 & 1.33 & 1.14 \\
\hline B14 & 0.1 & 78 & 6.6 & 1.15 & 1.26 & 1.13 & 1.05 \\
\hline B15 & 0.1 & 79 & $7.8(4.13)$ & 1.16 & 1.25 & 1.14 & 1.08 \\
\hline B16 & 0.1 & 78 & $7.9(5.17)$ & 0.97 & 1.04 & 0.96 & 0.94 \\
\hline B17 & 0.1 & 84 & 7.2 & 1.03 & 1.11 & 1.02 & 0.98 \\
\hline B18 & 0.1 & 80 & $8.3(5.2)$ & 1.08 & 1.15 & 1.07 & 1.05 \\
\hline B19 & 0.1 & 82 & $8.5(6.0)$ & 0.93 & 0.98 & 0.92 & 0.92 \\
\hline \multicolumn{4}{|c|}{ Mean } & 1.1 & 1.18 & 1.04 & 1.0 \\
\hline \multicolumn{4}{|c|}{ Standard Deviation } & 0.12 & 0.15 & 0.14 & 0.08 \\
\hline
\end{tabular}

* Values in parentheses are results of beams tested by Farahat [18], not subjected to axial forces.

\section{Validation of the Proposed Equation for Predicting Results from the Literature}

The proposed equation was used for predicting other results in the literature in order to extend its validity for prediction of shear strength for beams of different shear span-depth ratios, different longitudinal and web reinforcement ratios. The prediction was made for beams tested by Swamy and Bahia [4], Shin et al. [19], Cho and Kim [20], Ashour et al. [2] and Farahat [18] beside the beams tested in this study. These beams had a range of concrete strength (44-101 MPa), different amounts of fiber content (0 to $2 \%$ ), fiber aspect ratio (50 to 
133), shear span-depth ratio (1.3 to 6), longitudinal reinforcement ratio (2.9-5.4\%) and web reinforcement ratio $(0-1.12 \%)$. Figure 4 shows the ratio of the experimental to predicted results versus fiber content for 70 beams. It can be seen from the figure that the analytical predictions using the proposed equation are reasonably close to the test results of other researchers. Although the overall statistics are good, the equation is not conservative for a/d $=6$ (Ashour specimens [2]) as shown in Figure 4. Cho and Kim [20] observed similar findings in their study. This may be attributed to the empirical formulation and the representation of more slender beam behavior.

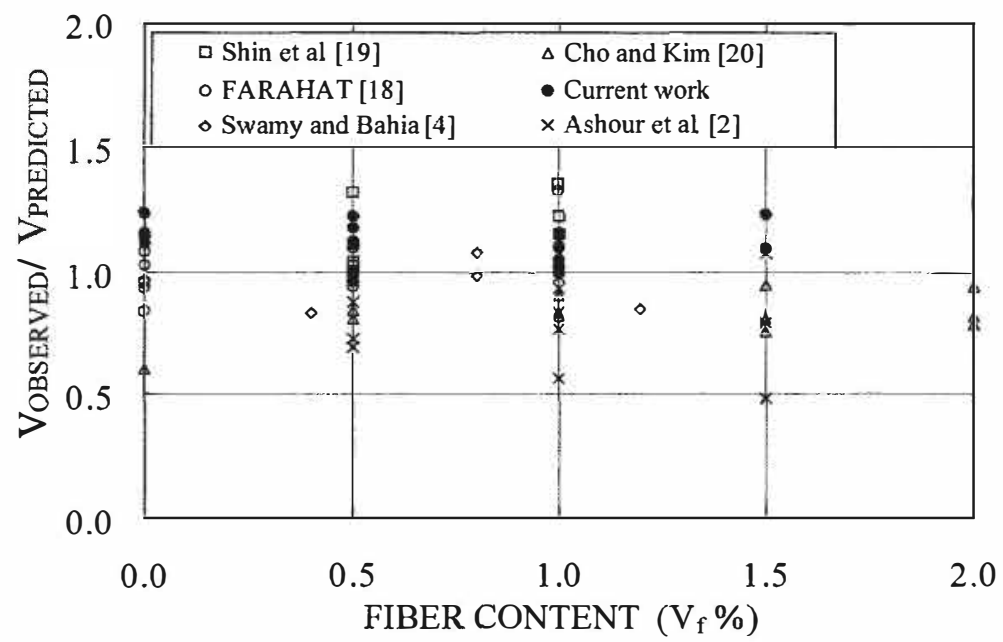

Figure 4 Validation of the proposed equation for predicting results of other tests.

\section{CONCLUSIONS}

A total of 19 HSFRC beams, containing longitudinal reinforcement and subjected to axial compression forces, were tested. Based on the experimental results and the analytical model developed in this research, the following conclusions were drawn:

1. Test results indicated that the addition of steel fibers enhanced initial stiffness, cracking loads, ultimate loads and, shear strength, and in turn, the ductility of the studied beams. Adding $0.5 \%$ fibers by volume resulted in increasing the cracking load and ultimate load by 14 and $17 \%$ over those of the reference beam. Increasing the fiber volume to $1.5 \%$ led to a further increase to cracking and ultimate loads by 41 and $48 \%$, compared to those of the reference beam. Regardless of the failure mode, fibrous concrete beams eventually collapsed from the severely localized deformations at one or two major cracks.

2. It was found that fiber reinforcement can reduce the amount of shear stirrups required, and that a combination of web reinforcement and fibers resulted in obtaining the benefit of both high capacity and ductility. This combination resulted in a significant increase in the cracking and ultimate loads by 123 and $59 \%$ over those of the reference beam specimen. The hooked-end fibers are slightly better than corrugated steel fibers in terms of raising the first crack load, increasing the capacity and ductility of studied beams. 
3. It was found that shear strength results for beams in the current investigation, subjected to axial compression stress equals 0.1 , are $22-98 \%$ higher than those tested by Farahat [18] without applying axial stress. Increasing the applied axial compression stress from 0.1 to 0.2 led to a maximum increase in the first crack load and ultimate load by 24 and $10 \%$, and a reduction of the deflection by $(19-30 \%)$ and it has almost the same effect as increasing the fiber content from 0.5 to $1 \%$ on the ultimate shear capacity of the tested beams. The effect of increase in axial compression stress level becomes less significant with the increase of percentage volume of fibers from $0.5 \%$ to $1.5 \%$.

4. A proposed equation was developed to predict shear strength of HSFRC beams with and without stirrups and subjected to axial compression stress. The results obtained using this equation were in good agreement with the experimental results of the tested beams and other results reported in the literature for a practical range of concrete strength, different amounts of fiber content, fiber type, fiber aspect ratio, shear span-depth ratio (including deep beams), longitudinal reinforcement ratio and web reinforcement ratio. The results obtained by the proposed equation were in better agreement with the test results (mean of 1.0 and standard deviation of 0.08 ) when compared with the predictions based on the empirical equations proposed by other investigators.

\section{ACKNOWLEDGEMENT}

The staff members and technicians of the Reinforced Concrete Testing Laboratory at Cairo University are acknowledged for their great help.

\section{REFERENCES}

1. NOGHABAI, K., "Beams of Fibrous Concrete in Shear and Bending: Experiment and Model" Journal of Structural Engineering, Vol. 126, No. 2, February, 2000, pp. 243-251.

2. ASHOUR, S.A., HASANAIN, G.S., and WAFA, F.F., "Shear Behavior of High-Strength Fiber Reinforced Concrete Beams," ACI Structural Journal, Vol. 89, No. 2, 1992, pp. 176-184.

3. EL-NIEMA, E.I., "Reinforced Concrete Beams with Steel Fibers under Shear," ACI Structural Journal, Vol. 88, No. 2, March-April, 1991, pp. 178-183.

4. SWAMY, R.N., and BAHIA, H.M., "Effectiveness of Steel Fibers as Shear Reinforcement," Concrete International: Design and Construction, Vol. 7, No. 3, Mar. 1985, pp. 35-40.

5. CRAIG, R. JOHN, "Structural Applications of Reinforced Fibrous Concrete," Concrete International: Design \& Construction, Vol. 6, No. 12, Dec. 1984, pp. 28-32.

6. ACI 544.4R-88, "Design Considerations for Steel Fiber Reinforced Concrete," State of the Art Report by ACI Committee 544, Reapproved 1999.

7. JOHNSON, M.K., and RAMIREZ, J.A., "Minimum Shear Reinforcement in Beams with Higher-Strength Concrete," ACI Structural Journal, Vol. 86, No. 4, July-Aug. 1989, pp. 376-382. 
8. OZCEBE, G., ERSOY, U., and TANKUT, T., "Evaluation of Minimum Shear Reinforcement Requirements for Higher-Strength Concrete," ACI Structural Journal, Vol. 96, No. 3, May-June 1999, pp. 361-368.

9. YANG, E.I., Yi, S.T., and MORITA, S., "Effect of Axial Restraint on Flexural and Shear Behavior of High-Strength Concrete Members," Magazine of Concrete Research, Vol. 56, No. 2, March, 2004, pp. 63-72.

10. MEGGET L. M. and FENWICK R. C., "Seismic Behavior of a Reinforced Concrete Portal Frame Sustaining Gravity Loads," Bulletin of the New Zealand National Society for Earthquake Engineering, 1989, 22, No. 1, 39-49.

11. ABDOUN, S. G. (1998) "Effect of Axial Compressive Stresses on Shear Strength of High Strength Concrete Beams with Web Reinforcement "Cairo University, Ph.D.

12. BALAGURU, P.N. and SHAH, S.P., "Fiber Reinforced Cement Composites," McGrawHill, Inc., 1992, p. 196.

13. OH, B. H., LIM, D. H., YOO, S. W. and KIM, E. S., "Shear Behavior and Shear Analysis of Reinforced Concrete Beams Containing Steel Fibers," Magazine of Concrete Research, Dec. 1998, Vol. 50, No. 4, pp. 283-291.

14. MPHONDE, A.G., "Aggregate Interlock in High-Strength Reinforced Concrete Beams," Proceedings of Institution of Civil Engineer: Part 2, Vol. 85, Sept. 1988, pp. 397-413.

15. NARAYANAN, R., and DARWISH, I. Y. S., "Use of Steel Fibers as Shear Reinforcement," ACI Structural Journal, Vol. 84, No. 3, May-June 1987, pp. 216-227.

16. ACI Committee 318, "Building Code Requirements for Structural Concrete (ACI 318-99) and Commentary (318R-99)," American Concrete Institute, Farmington Hills, Mich., 1999, $391 \mathrm{pp}$.

17. ECCS 203-2001, "Egyptian Code for Design and Construction of Concrete Structures", Cairo, Egypt, 2001.

18. FARAHAT, A.M., "Effectiveness of Steel Fibers on the Shear Resistance of HighStrength Reinforced Concrete Beams," Eng. Res. Journal, Helwan University, Vol. 91, Feb. 2003, pp. 35-55.

19. SHIN, S. W., OH, J., and GHOSH, S.K., "Shear Behavior of Laboratory-Sized HighStrength Concrete Beams Reinforced with Bars and Steel Fibers," Fiber Reinforced Concrete Developments and Innovations, SP-142, ACI, Farmington Hills, 1994, pp. 181200.

20. CHO and KIM, "Effects of Steel Fibers on Short Beams Loaded in Shear," ACI Structural Journal, Vol. 100, No. 6, Nov.-Dec. 2003, pp. 765-774. 